\title{
Analysis of Regional Competitiveness in West Sumatera
}

\author{
Nurul Andriana ${ }^{1}$, Syamsul Amar ${ }^{2}$, Hasdi Aimon ${ }^{3}$ \\ 1 Universitas Negeri Padang, Padang Indonesia, $\triangle$ andriananurul@bps.go.id \\ 2Universitas Negeri Padang, Padang Indonesia, \syamsul_amar2@yahoo.co.id \\ 3Universitas Negeri Padang, Padang Indonesia, \aimon_55@yahoo.co.id
}

\begin{abstract}
This study aims to measure the regional competitiveness index for all regencies and municipalities in West Sumatera Province. Using input factors as the main component in order to foster economic growth and regional development and also output factors as the goals of the development, this research used Analytical Hierarchy Process (AHP) for deciding on the decision-making process. Input factors were divided into three classifications, namely indicator, sub-indicator and variable level, while output factors consisted of merely 4 indicators. The highest weight of indicator input factors is human resource and employment, the highest weight of sub-indicator factors is Productive Business Environment (PBE) by Society, and the highest weight of variables is Life Expectancy. On the other hand, the highest weight of output factors is Employment Productivity. Based on the competitiveness index, municipalities in West Sumatera Province tend to have a higher index than regencies.
\end{abstract}

Keyword: competitiveness index, regional economic, analytical hierarchy process, west sumatera

\section{Introduction}

Nowadays, it becomes more important for a developing region to measure competitiveness in order to evaluate its regional economic development strategies. Competitiveness, too, is a crucial starting point because it leads to a higher living standard and generates the resources needed for more extensive goals (Schwab, 2018). This measurement could also drive to foster regional economic development by means of enhancing the leading input and output indicators, as well as reducing inequality. There is numerous evidence that economic growth has been the main feature in helping people to raise their standards of living and out of the poverty trap (Schwab, 2018).

Since competitiveness has become the main issue thanks to globalization (Bienkowski, 2009), every individual national or regional economy needs to measure competitiveness. Globally, the experts of the World Economic Forum (WEF) has formulated the Global Competitiveness Index (GCI), which is a figure of a country's potential for growth (Bienkowski, 2009). In other words, the GCI analyses the extent to which individual national economies have the structures, institutions, policies in place for economic development over the medium or long run period (McArthur \& Sachs, 2002).

Meanwhile, if the country sample for comparison is not well-designed, international comparison of competitiveness yielded from that calculation can be misleading and even wrong (Török, Borsi, \& Telcs, 2005). In general, sometimes, it could be misleading to compare countries with huge differences in economic development such as the size of the country, factors of competitiveness, or economic structures (Török, Borsi, \& Telcs, 2005). In order to avoid those incorrect comprehensions, it needs to define competitiveness well especially for the region that has a uniqueness. It cannot be shunned that every region has its characteristic in order to support its economic growth.

Regions have ambitions to strengthen their competitiveness as knowledge-based economies (Galama \& Hosek, 2008). So, based on the result of regional competitiveness measurement, it becomes easier to make strategies in terms of regional development. For instance, Masterplan of Planning and Accelerating Indonesia's Economic Development (MP3EI) 2011-2025 has mentioned that Sumatera region was decided as "The Centre of Production and Processing of Natural Resources as the Nation's Energy Reserves (Coordinating Ministry for Economic Affairs, Republic of Indonesia, 2011)." Thus, it 
implies that the main activities mentioned on MP3EI move from raw-material extraction to the processing of main commodities. For example, crude palm oils, rubbers, and coals, and advancement of shipbuilding and steel industries (Coordinating Ministry for Economic Affairs, Republic of Indonesia, 2011).

One of the possible region becoming the centre of national energy based on MP3EI is West Sumatera Province (Coordinating Ministry for Economic Affairs, Republic of Indonesia, 2011). The research of Tan Khee Giap et al in 2014 titled "Analysis of Province and Region Competitiveness, Keeping Indonesia's Growth Momentum" measured the competitiveness of West Sumatera as of 0.2179 and ranked it as of the seventeenth highest among Indonesian provinces (Tan, Merdikawati, Amri, \& Tan, 2015). In order to enrich the sources of West Sumatera Province competitiveness, using Analytical Hierarchy Process (AHP), this paper is to measure the competitiveness of West Sumatera Province. The AHP is designed to solve decision-making problems with multiple criteria.

The rest of this study is structured as follows. Section 2 explores the literature review and the findings of the previous researches. Section 3 describes the method used in this study. Section 4 reveals the results and discusses of research findings. Finally, Section 5 presents the conclusion of this research.

The AHP is the basic tools to decision making, which is based on a general theory of measurement (Saaty \& Vargas, 2012). It is designed to deal with both rational decision and intuitive judgement to select the best number represented several criteria (Saaty \& Vargas, 2012). Generally speaking, the AHP could not only be used to establish measure in physical but also social domains (Saaty \& Vargas, 2012). There are numerous studies using AHP in order to measure global and sector competitiveness, but there remains scarce using AHP to measure regional competitiveness in Indonesia especially for developing province which has several unique characteristics such as West Sumatera Province.

Many studies using AHP are conducted in order to measure the competitiveness of particular sectors such as public transport competitiveness (Boujelbene \& Derbel, 2015), firm competitive advantages (Fundeanu \& Badele, 2013), airlines competitiveness (Delbari, Ng, Aziz, \& Ho, 2016), port competitiveness (Peng, et al., 2018), tourism destination competitiveness (Michael, Reisinger, \& Hayes, 2019) (Zhou, Maumbe, Deng, \& Selin, 2015), and Human Resources Science Technology (HRST) competitiveness (Chou, Hsu, \& Yen, 2008). Overall, those papers were to be able to determine the indicators, sub-indicators and criteria competitiveness weight in each sector. By evaluating and enhancing competitiveness from those studies, it would be easier to gain profitability and performance.

As mentioned above, there remains scarce that studies using AHP were used in order to measure the regional competitiveness, especially in developing country and province such as West Sumatera Province, which has a huge difference from another region in Indonesia. There are studies measuring regional competitiveness, but the methods used in those studies are Data Envelopment Analysis (DEA) and principal component analysis. For example, establishing an index using principal component analysis in order to measure urban competitiveness in Shandong Province (Peng \& Zhanxin, 2010), and calculating regional competitiveness using DEA in Peru (Charles \& Zegarra, 2014).

The main finding of those two research papers is that the competitiveness resulted from the calculation is uneven among regions, so there would be recommendations to the government to create a development strategy in order to raise the competitiveness in all regions

\section{Methods}

Data used in this research is primary and secondary data obtained from the government such as BPS-Statistics Indonesia West Sumatera Province, and experts from each regency/municipality in West Sumatera Province. Primary data in this research was qualitative opinion based on expert responses, whereas secondary data was acquired from several official institutions both central and regional government. 
Primary data in this study was collected using a questionnaire, which experts were expected to answer all of the questions and fulfil the questionnaire by themselves (self-enumeration). Each regency/municipality was represented by two experts who came from two institutions, namely Region Finance Agency (BKD) and Regional Development Planning Agency (Bappeda). In addition, two experts, too, came from province institution. So, a number of experts expected to be the respondent of this study were 40 people. Unfortunately, there were mere 24 experts who were willing to respond to the questionnaire completely and sent it back. They were from 13 regencies/municipalities in West Sumatera Province.

Meanwhile, secondary data was obtained by collecting official data released by the government such as BPS-Statistics Indonesia West Sumatera Province (Badan Pusat Statistik, 2018). Those data were classified to be input factors and output factors. In this research, there were 33 variables of input factors and 4 variables of output factors.

There are several steps to measure West Sumatera competitiveness index. Firstly, weighing the perception data from experts to the initiative strategy of gaining the region competitiveness; secondly, doing data and indices standardisation. Competitiveness index is the composite index between input and output factors.

Weighting measurement from expert perceptions will be done using a method called Analytical Hierarchy Process (AHP), which was first introduced by Thomas L. Saaty in the 1970s. AHP is the structural method for processing the organization for complex decision making, which also takes mathematics and psychology as considerations (Kementrian Keuangan Republik Indonesia, 2014). Before weighting, it needs to collect data from experts in each regency/municipality. In this research, experts are the people who comprehend well all the regional problems as well as their solution in order to improve regional competitiveness. Weighting process was not only done for input factors but also for output factors.

Next step is data standardisation. Standardization is done by dividing expert data from each regency/municipality with an average of all data on the relevant variables. This aims to eliminate the influence of the units of each variable which previously had different units.

\section{Results and Discussion}

The regional competitiveness index is an index that depicts the strengths and capabilities possessed by a region. This index contains two factors, namely input factors and output factors. As mentioned earlier, in this study, there are 33 input factor variables and 4 output factor variables. The stages for measuring the competitiveness index are; first, calculate the weight of the expert opinion based on interviews. Second, standardise the data and variables collected from BPS and other government institution. Standardization has a purpose for eliminating the effect of units that vary between variables.

\section{Measurement of Input and Output Factor Weight}

There are three steps in describing the input factors in order to enhance the regional competitiveness, namely the level of indicators as many as 5 indicators, the level of sub-indicator as many as 12 indicators, and the level of the variable as many as 33 variables. The results of each can be summarised at the following tables.

From table 1 bellow, according to experts, the most important factor input indicator is human resource and employment as accounted for 31.6 per cent. Meanwhile, the least important factor input indicator is the banking and financial institution indicator as noted around 13.8 per cent.

Human resources and employment indicator is the most important priority to enhance regional competitiveness. Next, three indicators, namely regional economy, productive business environment and natural resource infrastructure and environment indicator, were accounted for around 18.1 to 18.4 per cent. 
Table 1 The Weight of Input Factor Indicator

\begin{tabular}{clc}
\hline Priority & \multicolumn{1}{c}{ Indicator } & Weight (\%) \\
\hline $\mathbf{( 1 )}$ & \multicolumn{1}{c}{$(\mathbf{2})$} & $\mathbf{( 3 )}$ \\
\hline 1 & Regional Economy & 18.40 \\
\hline 2 & Human Resource and Employment & 31.60 \\
\hline 3 & Productive Business Environment & 18.10 \\
\hline 4 & Natural Resource Infrastructure and Environment & 18.10 \\
\hline 5 & Banking and Financial Institutions & 13.80 \\
\hline \multicolumn{2}{c}{ Total } \\
\hline
\end{tabular}

Source: Data Analysis, 2015.

Then, the analysis is continued to the sub-indicator level of input factor, which can be seen at the table 2 below.

Table 2 The Weight of Input Factor Sub Indicator

\begin{tabular}{clr}
\hline Priority & \multicolumn{1}{c}{ Sub Indicator } & Weight (\%) \\
\hline $\mathbf{( 1 )}$ & \multicolumn{1}{c}{$(\mathbf{2})$} & $\mathbf{( 3 )}$ \\
\hline 1.1 & Sectoral Productivity & 34.00 \\
\hline 1.2 & Regional Finance & 26.90 \\
\hline 1.3 & Investment Openness and Regional Expenses & 39.10 \\
\hline & Regional Economy & 100.00 \\
\hline 2.1 & Human Resource & 64.40 \\
\hline 2.2 & Employment & 35.60 \\
\hline & Human Resource and Employment & 100.00 \\
\hline 3.1 & PBE by Government & 33.10 \\
\hline 3.2 & PBE by Society & 66.90 \\
\hline & Productive Business Environment (PBE) & 100.00 \\
\hline 4.1 & Transportation and Communication Condition & 42.60 \\
\hline 4.2 & Energy Condition & 27.20 \\
\hline 4.3 & Natural Resource and Environment Condition & 30.30 \\
\hline & Natural Resource Infrastructure and Environment & 100.00 \\
\hline 5.1 & Banking and Non-banking Infrastructure & 49.20 \\
\hline 5.2 & Banking Performance and Financial Sector & 50.80 \\
\hline & Banking and Financial Institutions & 100.00 \\
\hline
\end{tabular}

Source: Data Analysis, 2015. 
Table 3 The Weight of Input Factor Variables

\begin{tabular}{|c|c|c|}
\hline Priority & Variables & Weight $(\%)$ \\
\hline (1) & $(2)$ & (3) \\
\hline 2.1 .4 & Life Expectancy & 6.80 \\
\hline 3.1.1 & Per capita Public Service Expenditures & 5.99 \\
\hline 2.1 .3 & Mean Years of Schooling & 5.92 \\
\hline 2.2 .1 & Number of Employment & 5.84 \\
\hline 2.2 .2 & Employment Growth & 5.41 \\
\hline 5.1 .2 & Business Volume to Number of Cooperatives Ratio & 4.83 \\
\hline 2.1 .2 & Dependency Ratio & 4.68 \\
\hline 3.2 .1 & Number of Regional Base Sectors & 4.12 \\
\hline 4.1 .2 & Percentage of Asphalt Road Villages & 3.31 \\
\hline 5.2 .3 & Per capita Value Added of Financial Sectors & 3.17 \\
\hline 4.1 .1 & Per capita Value Added of Transportation Sectors & 3.16 \\
\hline 1.2 .1 & Regional Fiscal Capacity & 3.04 \\
\hline 2.1 .1 & Population & 2.95 \\
\hline 3.2 .3 & Poverty Gap Index & 2.79 \\
\hline 3.2 .2 & Percentage of Population with University Education & 2.70 \\
\hline 1.3 .2 & Regional Expense Index & 2.60 \\
\hline 1.1 .1 & Primary Sector Productivity & 2.56 \\
\hline 3.2 .4 & Population Density & 2.51 \\
\hline 1.3 .1 & Per capita Investment & 2.30 \\
\hline 1.3 .3 & Firm Density & 2.30 \\
\hline 4.3 .1 & Productive Land Area to Total Harvest Area Ratio & 2.14 \\
\hline 1.1 .2 & Secondary Sector Productivity & 2.11 \\
\hline 5.2 .1 & Total Banking Credit & 2.06 \\
\hline 4.3 .3 & Per capita Value Added of Mining Sector & 2.03 \\
\hline 5.1.1. & Number of Cooperatives & 1.96 \\
\hline 1.2 .2 & Government Size & 1.91 \\
\hline 4.2 .1 & Per capita Industry and Household Electricity Consumption & 1.86 \\
\hline 5.2 .2 & Deposits to Commercial Banks and Rural Banks & 1.78 \\
\hline 4.2 .2 & Per capita Electricity Production & 1.62 \\
\hline 1.1 .3 & Tertiary Sector Productivity & 1.58 \\
\hline 4.2 .3 & Per capita Industry and Household Fuel Consumption & 1.44 \\
\hline 4.3 .2 & Per capita Water Resources & 1.31 \\
\hline \multirow[t]{2}{*}{4.1 .3} & Percentage of Households who have landlines & 1.24 \\
\hline & & 100.00 \\
\hline
\end{tabular}

Source: Data Analysis, 2015.

Even though the most important indicator is human resource and employment, the highest subindicator weight of input factor is Productive Business Environment (PBE) by Society at productive business environment indicator level as of 66.9 per cent. But, the second place is the human resource from human resource and employment indicator level, which was accounted for 64.4 per cent. In the meantime, other sub-indicator percentages are relatively even, at around or less than 50 per cent.

On the variable level (Table 3), the input factor which has the highest score is Life Expectancy as noted by 6.8 per cent. In the meantime, the smallest value at the variable levels is Percentage of Households who have landlines as accounted for 1.24 per cent. Life expectancy is the variable under human resources and employment indicator level. Based on the high score on indicators, subindicators and variables, it seems human resources and employment to be the main factors for enhancing competitiveness at the regional level in West Sumatera Province. 
Weighting process is not only at input factors, which starting from the indicator, sub-indicator and variable level, but also at output factors. As explained above, the number of output factors is only 4 indicators, namely employment productivity, employment opportunity level, Per Capita Gross Regional Domestic Product (GRDP), and percentage of poor people. Those indicators are the aims of regional economic development.

Table 4 The Weight of Output Factor Indicator

\begin{tabular}{clc}
\hline Priority & \multicolumn{1}{c}{ Indicator } & Weight (\%) \\
\hline $\mathbf{( 1 )}$ & \multicolumn{1}{c}{$(\mathbf{2})$} & $\mathbf{( 4 )}$ \\
\hline 1 & Employment Productivity & 35.10 \\
\hline 2 & Employment Opportunity Level & 32.50 \\
\hline 3 & Per Capita GRDP & 19.0 \\
\hline 4 & Percentage of Poor People & 13.40 \\
\hline & & 100.00 \\
\hline
\end{tabular}

Source: Data Analysis, 2015.

Table 4 depicts the fact that the highest weight of the output factors is employment productivity, namely 35.1 per cent. At the next place, there is employment opportunity level (32.5 per cent), per capita GRDP (19 per cent) and the percentage of poor people (13.4 per cent)

\section{Indices and Ratios Consistency Testing}

The response of experts needs to be tested whether it was consistent or not. The limitation figure in this study is 10 per cent or less. This testing is to guarantee that the responses of experts are logic so that the competitiveness measurement can be conducted. According to 24 experts, the inconsistency of their answers is mere 0.01 or only 1 per cent.

\section{Competitiveness Index Measurement}

After obtaining input factors, from the indicator, sub-indicator to variable level, also after standardising the data and indices, the next step is measuring the competitiveness index. As explained earlier, the competitiveness index is the composite index of input and output factors.
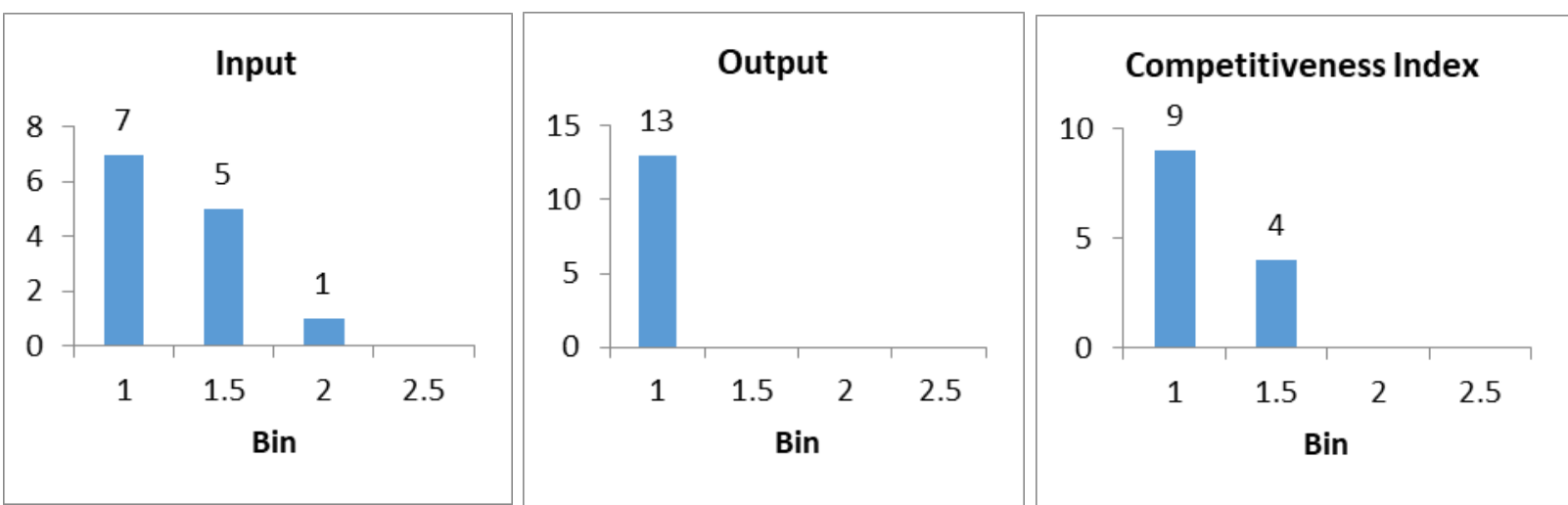

Figure 1 Histogram of Input and Output Index

Source: Data Analysis, 2015.

Figure 1 above illustrates the frequencies of input, output and competitive index as a result of the measurement. It is obvious that the majority of regencies/municipalities have input index as of less than one. On the other hand, all regencies/municipalities have output index as of less than one. Moreover, the competitiveness index of thirteen regencies/municipalities is around less than one as accounted for 9 regencies/municipalities, while that around less than 1.5 as many as 4 regencies/municipalities. 


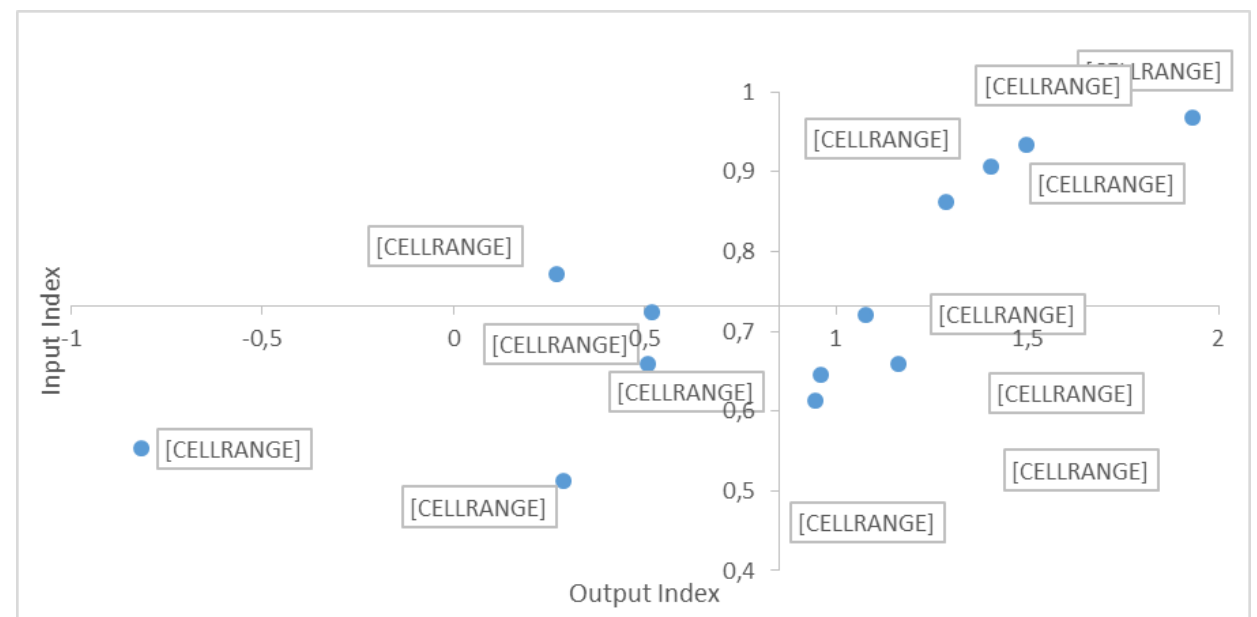

Figure 2 Regencies/Municipalities Based on Input and Output Index Source: Data Analysis, 2015.

There are four regencies that have input and output index below the average, namely Pasaman, Dharmasraya, Pesisir Selatan and Agam Regency. On the other hand, there are also four municipalities that have input and output index below the average, those are Bukittinggi, Padang, Pariaman and Solok Municipality. It seems to be clear that there is unequal competitiveness between regencies and municipalities in West Sumatera Province.

From figure 3 below, it is clear that the input index has the main role in determining the competitiveness index. Even though the input index started from the highest value, the competitiveness index is not as high as expected because of the lower output index.

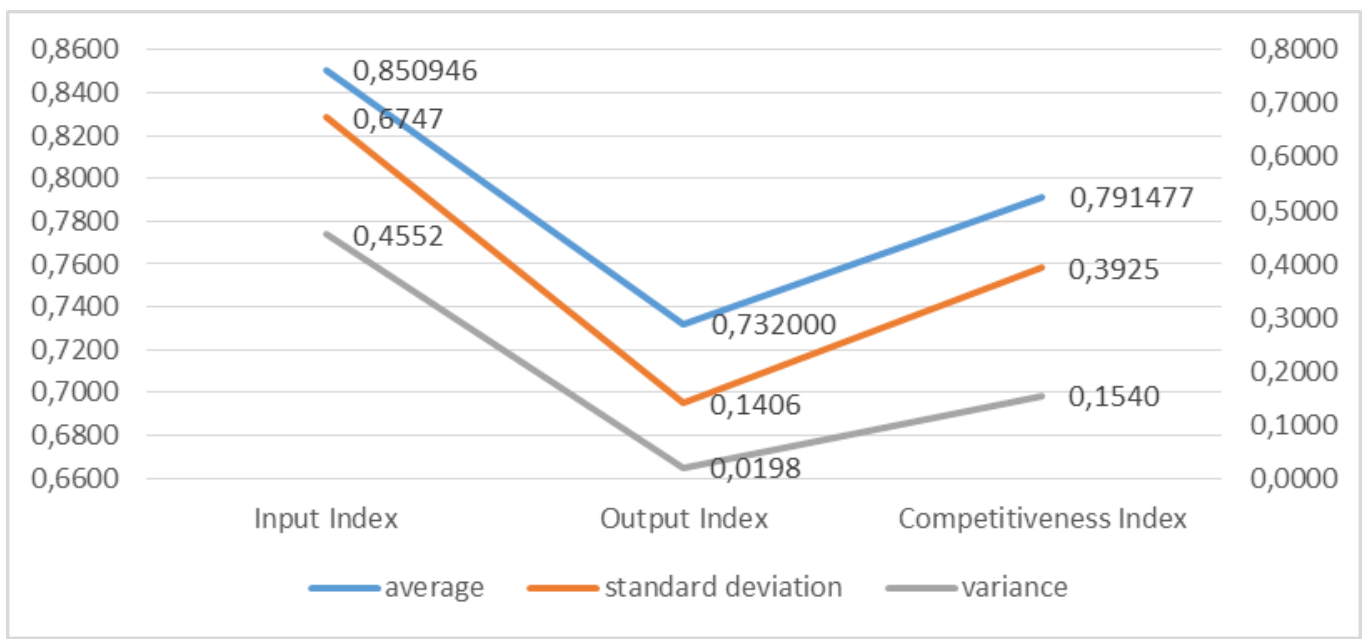

Figure 3 The Dispersion of Input, Output and Competitiveness Index

Source: Data Analysis, 2015.

It can be seen from table 5 that municipalities in West Sumatera tend to have a higher competitiveness index than regency. For instance, Padang Municipality (1.4498), Bukittinggi Municipality (1.2161), Solok Municipality (1.564) and Pariaman Municipality (1.0757). On the other hand, the competitiveness index in several regions remains at a low level such as Pesisir Selatan Regency (0.4001), Padang Pariaman Regency (0.5216) and Agam Regency (0.5841).

In the meantime, a range of competitiveness index between the highest and the lowest is around 1.5806. Competitiveness index is mainly dominated by input factors, whose range reach 2.7470 , whereas output factors are only about 0.4545 . This indicates that input factors vary more than output factors. 
Table 5 Input Factor, Output Factor, and Competitiveness Index Based on Regency/Municipality in West Sumatera

\begin{tabular}{clccc}
\hline No & Regency/Municipality & $\begin{array}{c}\text { Input } \\
\text { Factor }\end{array}$ & $\begin{array}{c}\text { Output } \\
\text { Factor }\end{array}$ & $\begin{array}{c}\text { Competitivenes } \\
\text { s Index }\end{array}$ \\
\hline 1 & Kep. Mentawai & 0.9469 & 0.6119 & 0.7794 \\
\hline 2 & Pesisir Selatan & 0.2882 & 0.5120 & 0.4001 \\
\hline 3 & Sijunjung & 1.1656 & 0.6584 & 0.9120 \\
\hline 4 & Padang Pariaman & 0.2718 & 0.7713 & 0.5216 \\
\hline 5 & Agam & 0.5097 & 0.6585 & 0.5841 \\
\hline 6 & Lima Puluh Kota & 0.9631 & 0.6444 & 0.8037 \\
\hline 7 & Pasaman & -0.8139 & 0.5523 & -0.1308 \\
\hline 8 & Dharmasraya & 0.5208 & 0.7231 & 0.6219 \\
\hline 9 & Padang & 1.9330 & 0.9665 & 1.4498 \\
\hline 10 & Kota Solok & 1.4081 & 0.9047 & 1.1564 \\
\hline 11 & Bukittinggi & 1.4996 & 0.9325 & 1.2161 \\
\hline 12 & Payakumbuh & 1.0786 & 0.7198 & 0.8992 \\
\hline 13 & Kota Pariaman & 1.2908 & 0.8606 & 1.0757 \\
\hline Minimum & -0.8139 & 0.5120 & -0.1308 \\
\hline Maximum & 1.9330 & 0.9665 & 1.4498 \\
\hline Range & & 2.7470 & 0.4545 & 1.5806 \\
\hline
\end{tabular}

Source: Data Analysis, 2015.

Figure 4 below support what has been captured on table 5 above. From this figure, it can be clearly seen what makes the indices of each region either high or low. As depicted below, Padang has the highest competitiveness index thanks to a higher both input and output indices.

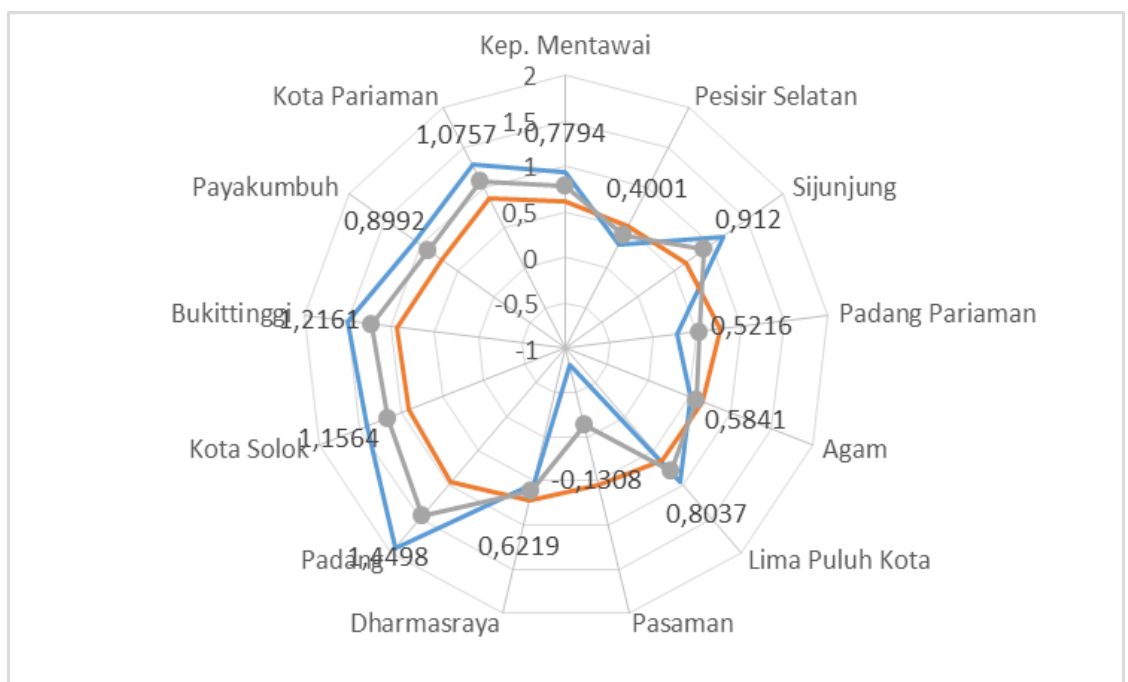

Figure 4 The Dispersion of Input, Output and Competitiveness Index

Source: Data Analysis, 2015.

\section{Conclusions}

Weighting on the data and index in this study is implemented not only for input factors, which include indicators, sub-indicators, and variables but also for output factors. According to expert opinion, input factor indicator which has the highest weight is human resources and employment. 
Next, the input factor sub-indicator which has the highest weight is Productive Business Environment by Society. Finally, the input factor variable which has the highest weight is Life Expectancy.

Meanwhile, at the output factors, experts argue that regional development strategy plays a predominant role in creating output, whose the highest weight is Employment Productivity. On the other hand, the lowest output factor weight is the percentage of poor people.

In West Sumatera Province, regions which have a high competitiveness index are more likely municipality region. Measurement of the competitiveness index of West Sumatera Province is more dominated by input factors than output factors. This, too, indicates that input factors in this province are more important than output factors.

\section{References}

Badan Pusat Statistik. (2018). Produk Domestik Regional Bruto Provinsi Sumatera Barat Menurut Lapangan Usaha 2013-2017. Padang: Badan Pusat Statistik.

Bienkowski, W. (2009). Competitiveness of New Europe. New York: Routledge.

Boujelbene, Y., \& Derbel, A. (2015). The performance analysis of public transport operators in Tunisia using AHP method. The International Conference on Advanced Wireless, Information, and Communication Technologies (AWICT 2015). Tunisia.

Charles, V., \& Zegarra, L. F. (2014). Measuring regional competitiveness through Data Envelopment Analysis: A Peruvian case. Expert Systems with Applications(41), 5371-5381.

Chou, Y.-C., Hsu, Y.-Y., \& Yen, H.-Y. (2008). Human resources for science and technology: Analyzing competitiveness using the analytic hierarchy process. Technology in Society(30), $141-153$.

Coordinating Ministry for Economic Affairs, Republic of Indonesia. (2011). Masterplan for Accelerating and Expansion of Indonesia Economic Development 2011 - 2025. Jakarta: Coordinating Ministry for Economic Affairs, Republic of Indonesia.

Delbari, S. A., Ng, S. I., Aziz, Y. A., \& Ho, J. A. (2016). An investigation of key competitiveness indicators and drivers of full-service airlines using Delphi and AHP techniques. Journal of Air Transport Management(52), 23-34.

Fundeanu, D. D., \& Badele, C. S. (2013). The impact of regional innovative clusters on competitiveness. 12th International Symposium in Management. Timisoara, Romania.

Galama, T., \& Hosek, J. (2008). U.S. Competitiveness in Science and Technology. Santa Monica: the RAND Corporation.

Kementrian Keuangan Republik Indonesia. (2014). Kajian Atas Kebijakan Penguatan Daya Saing Daerah Dalam Rangka Peningkatan Kesejahteraan Masyarakat.

McArthur, J., \& Sachs, J. (2002). The growth competitiveness index: Measuring technological advancement and the stages of development, in The Global Competitiveness Report 2001-2002. Geneva: World Economic Forum Publications.

Michael, N., Reisinger, Y., \& Hayes, J. (2019). The UAE's tourism competitiveness: A business perspective. Tourism Management Perspectives(30), 53-64.

Peng, L., \& Zhanxin, M. (2010). The Evaluation of City Competitiveness in Shandong Province. International Conference on Energy, Environment and Development. Kuala Lumpur, Malaysia.

Peng, P., Yang, Y., Lu, F., Cheng, S., Mou, N., \& Yang, R. (2018). Modelling the competitiveness of the ports along the Maritime Silk Road with big data. Transportation Research Part A(118), 852-867.

Saaty, T., \& Vargas, L. (2012). Models, Methods, Concepts \& Applications of the Analytic Hierarchy Process Second Edition. New York: Springer Science+Business Media.

Schwab, K. (2018). The Global Competitiveness Report 2018. Geneva, Switzerland: World Economic Forum.

Tan, K. G., Merdikawati, N., Amri, M., \& Tan, K. Y. (2015). 2014 Provincial and Inaugural Regional Competitiveness Analysis; Safeguarding Indonesia's Growth Momentum. Singapore: Asia Competitiveness Institute - World.

Török, Á., Borsi, B., \& Telcs, A. (2005). Competitiveness in Research and Development: Comparisons and Performance. Cheltenham: Edward Elgar Publishing Limited. 
Zhou, Y., Maumbe, K., Deng, J., \& Selin, S. (2015). Resource-based destination competitiveness evaluation using a hybrid analytic hierarchy process (AHP): The case study of West Virginia. Tourism Management Perspectives(15), 72 -80. 